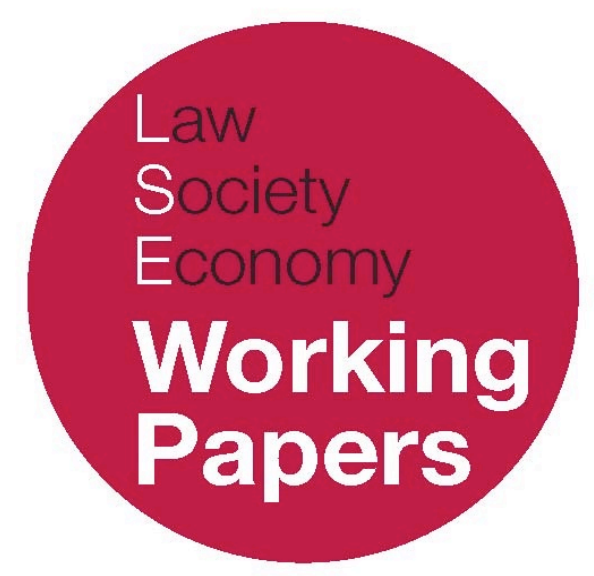

\title{
Public Law and the Autonomy of the Political: A Material Critique
}

\author{
Michael A. Wilkinson \\ Forthcoming in M. Wilkinson and M. Dowdle (eds.) Questioning the Foundations \\ of Public Law (Hart Publishing, 2018)
}

LSE Law, Society and Economy Working Papers 17/2017

London School of Economics and Political Science

Law Department

This paper can be downloaded without charge from LSE Law, Society and Economy Working Papers at: www.lse.ac.uk/collections/law/wps/wps.htm and the Social Sciences Research Network electronic library at: https://ssrn.com/abstract $=3063210$

(C) Michael A. Wilkinson. Users may download and/or print one copy to facilitate their private study or for non-commercial research. Users may not engage in further distribution of this material or use it for any profit-making activities or any other form of commercial gain. 


\title{
Public Law and the Autonomy of the Political: A Material Critique
}

\author{
Michael A. Wilkinson *
}

\begin{abstract}
Modern public law, according to Martin Loughlin's Foundations of Public law, depends upon the autonomy of the political realm. This is explained on the basis of an orthodox secularisation thesis of modernity, the autonomy of the political emerging through its successful separation from the theological. But when viewed in relation to the economic (the material realm), the autonomy of political ordering looks more fragile, subject to the continuing struggle between democracy and capitalism. The concrete features of this struggle are explored by way of a stylised diachronic overview of the transformation of the Western European state and regional state-system in the twentieth century, first with the interwar breakdown of political order, then with postwar reconstruction in the project of European integration. In the recent Eurocrisis phase it again enters a critical period. All of this, however, escapes the lens of a purely political jurisprudence.
\end{abstract}

\footnotetext{
* Associate Professor of Law, LSE. This chapter is forthcoming in Michael A. Wilkinson and Michael W. Dowdle (eds.) Questioning the Foundations of Public Law (Hart Publishing, 2018)
} 


\section{INTRODUCTION}

The conceptual history outlined in Martin Loughlin's Foundations of Public Law depends for its concrete success on the modern European state of the 'long 19th century' (the period from the French Revolution to the First World War). Central to this reconstruction is the idea of the 'autonomy of the political realm'. This is largely accounted for by an orthodox secularisation thesis of modernity, claiming the autonomy of the political from the theological domain. Loughlin advances his own account of the foundations of public law by insisting, persuasively, that secularisation does not mean sheer legal positivisation. Public law does not become freestanding or self-executing through its modernisation: it depends upon a political order to sustain it. This political order, or more accurately, the process of political ordering (to convey its dynamic quality) is conceptualised in the language of droit politique (political right) or, as in the opening chapter to this collection, 'political jurisprudence'. Political ordering stands in an internal relation to the positive law; this is by no means a straightforward coupling, it is a complex and potentially fraught relation. But secularisation does clear the way for a prudential science of political right, a 'pure theory' of public law, - and all the difficulties that come with reconciling the claim to prudential and scientific logics. ${ }^{1}$

But what does the autonomy of the political look like if viewed in relation to the economic, rather than the religious worldview? How does the political ordering of public law stand in relation to the material reproduction of society? It might be said that political jurisprudence supposes a relative autonomy from this realm as well. There is no autonomy of the political if, for example, political power is determined by economic power or specific class interests; if the political is a mere super-structural reflection of a material base, to adopt the Marxian metaphor. The autonomy of the political requires that the governing relationship in the modern state does not rest on the explicit fusion of political and economic power: it is the autonomy of the political from the economic that sustains the authority and legitimacy of the ruling relationship, and distinguishes modern statehood from previous political forms. ${ }^{2}$

Loughlin is occasionally explicit about this, if less in Foundations than elsewhere in his work. Political relationships, he notes, cannot be reduced to socio-economic relations, political power is not reducible to economic power, political office is not based on property rights, subjects are to be considered 'citizens' rather than 'labourers, capitalists, or bourgeoisie', and so on. ${ }^{3}$

\footnotetext{
${ }^{1}$ See also Panu Minkinnen, this volume.

${ }^{2}$ For extended discussion, see E Wood, From Lords to Citizens: A Social History of Western Political Thought (London, Verso, 2011).

${ }^{3}$ See M Loughlin, 'Political Jurisprudence', this volume, and earlier, e.g. 'Ten Tenets of Sovereignty' in N Walker (ed.) Sovereignty in Transition (Oxford, Hart, 2003).
} 
But what kind of claims are these? This autonomy, even 'primacy', of the political over the economic is asserted by way of conceptual stipulation, rather than explained through any historical reconstruction. Unlike the autonomy of the political from the theological realm, Loughlin does not offer even a brief narrative of their relation; he gives no account, for example, of how political power is separated from economic power or how this is sustained in the modern state. Just as significantly, there is no sense of how the political might be threatened, subsumed or transformed by - from the other side - an autonomous 'economic realm' working on the basis of a distinct market logic. The autonomy of the political from the economic is instead presupposed; the basic relation between political ordering and the reproduction of material social relations is essentially implicit in Foundations. ${ }^{4}$ All, that is, until its closing stages, a point to which we shall shortly return.

A more direct way of putting this is to say that the capitalist state, unlike the secular state, the state which distinguishes itself from market (rather than clerical) power receives little, if any, attention. The bearing of material questions on the process of political ordering takes a back stage: relations between capital and labour, debtors and creditors, core and peripheral nations, the role of political economic strategies, mercantilism and colonial expansion, the role of taxation and control of the money supply - are all avoided. Processes of commodification, and the dynamic relation between public political power and private economic power, between public goods and private ownership, between solidarity and competition, or community and individualism, remain under-examined. Relations of material equality and inequality, domestically, and in the uneven and combined development of global and regional economic systems, play little or no role in explaining the constitution of the modern state and the modern state-system.

The foundations of public law as presented by Loughlin indeed flatten or screen out material social relations, informal hierarchies, and more generally the persistence of socio-economic inequalities and class divisions, through the employment of terms such as 'political unity', 'the people' and 'popular sovereignty', however symbolic or reflexive their reprisal. ${ }^{5}$ Material relations are also flattened out geo-politically, in a world order sustained through the sovereign equality of states, rather than through imperialism, colonialism, or other forms of domination within and between states or regional organisations. The state is the unity of an undifferentiated multitude in this vision; political ordering is the process of achieving a (symbolic) juristic unity.

\footnotetext{
${ }^{4}$ These dual stories of differentiation of the political from the theological on the one hand, and the economic on the other, might of course themselves be inter-connected, in the relationship between secularisation and capitalism from the Reformation through the protestant work ethic, as outlined by Max Weber. But there is nothing to suggest that Loughlin endorses this Weberian story and Weber does not feature heavily in Foundations.

${ }^{5}$ See Loughlin, 'Political Jurisprudence', this volume.
} 
This absence gives political jurisprudence a formalistic character, despite drawing on an extraordinarily rich array of sources. There are, we are told, always 'rulers and ruled'; but we are never told how relative positions of ruling power are obtained, contested, or changed, and what the role of public law is in establishing, maintaining or contesting them. We are told that public law provides a rule-based guide to the management of conflict; and that conflict will never be fully or finally resolved. But the account of underlying conflict is essentially Hobbesian - abstract rather than historicised, based on an irreconcilable contest intrinsic to human nature rather than material inequalities, social hierarchies, class divisions, interstate domination or imperial rivalries. ${ }^{6}$

In other words, the political economy of the modern state and statesystem, unlike its political secularity, is irrelevant or only marginally relevant for framing political jurisprudence, a kind of irritant which can be kept external to political ordering. Although Loughlin hints at an exception to this elision beginning with the Rousseauvian imperative to avoid 'extreme inequality of fortunes', ${ }^{7}$ and continuing in Hegel's concern with the inequalities produced by the workings of natural law in civil society, ${ }^{8}$ the theme of inequality remains marginal in Foundations and is certainly not structural.

But why might this be considered theoretically problematic rather than merely a choice of emphasis? After all, even within the Marxist tradition, the juridico-political life of the capitalist state has come to be recognised as relatively autonomous, if in the last instance determined by the material base. 9 Another way of putting the question is to ask what does the presupposition of the (relative) autonomy of the political from the economic conceal?

Two related responses to this question can be given at the outset because they inform the chapter as a whole. The first goes to the dynamic quality of the ruling relationship, a relationship that is central to Loughlin's juristic point of view. If material social relations can be marginalised in a political order which is characterised by, and depends on, the accepted idea of a particular ruling class or fixed arrangement of political power (e.g. aristocracy), they are problematised in an order which claims to be democratic in form, which aspires, one might say, to the complete interchangeability of rulers and ruled, or to some notion of political equality. ${ }^{10}$ Claude Lefort's conception of the autonomy of the political, which Loughlin leans on, is nothing without the democratic impetus, beginning with the bourgeoisie revolutions of popular sovereignty at the end of the $18^{\text {th }}$ century but continuing through the struggles for universal suffrage, and in its broader distinction with modern totalitarianism into the $20^{\text {th }}$ century. This is because

\footnotetext{
${ }^{6}$ Cf. Anna Yeatman, this volume.

7 See Foundations, e.g. at 119, 428

8 See Foundations, e.g. at 349-350

9 See, especially, N. Poulantzas, State, Power, Socialism (London, Verso, 1980).

${ }^{10}$ Loughlin doesn't spell out what political equality means, but it clearly plays a central conceptual role for him. As Halpin notes, this volume, the 'equality premise' is problematic, rich and complex, yet undertheorised by Loughlin.
} 
Lefort's autonomy of the political, the 'empty place of power', is underpinned not just by secularisation but by the move from absolutism to democracy; it is through democracy as a social regime that political indeterminacy is maintained. ${ }^{11}$

But does Lefort - and following him, Loughlin - underestimate the role of economic power in the material constitution of a society which is not just democratic but also capitalist in form, where the empty place of power is in danger of being 'filled'? The suggestion here is that the autonomy of the political on which public law rests should be approached less as a one-off rupture, and more as a continuous democratic and political struggle for the place of power to remain 'empty'- one that is fully material in nature because it has to contend with the dynamics of economic (and geo-economic) systems and the inequalities they generate. This has only become more pressing in the struggle against the increasingly conspicuous inequalities of advanced capitalism in the $21^{\text {st }}$ century and new regimes of 'total market thinking' that threaten to erode the autonomy of the political. ${ }^{12}$

The second, related, point speaks to the episodic crises of legitimacy of the modern state and state-system. That this might be problematic is evident from within Foundations itself, with Loughlin briefly recognising towards the end that public law comes under severe strain in the late $20^{\text {th }}$ century with the 'triumph of the social'. ${ }^{13}$ But what is this a crisis of? Because of the insistence on secularism at the start, Loughlin is tempted into claiming that the crisis reflects a return of claims to religious truth but now in the form of objective social law; it is this that disrupts the interplay of political jurisprudence, threatening the distinctions on which public law rests, between state and society, private and public, inside and outside the sovereign state. ${ }^{14}$ Since Foundations is built on the displacement of the theological, it is natural to suppose that crisis coincides with its resurfacing. ${ }^{15} \mathrm{But}$ is it plausible to suggest that modern crises can be made sense of predominantly in terms of the collapse of the dichotomy between public reason and religious truth? Is 'the social' really just a stand-in for 'the religious'?

From a material perspective, the strains on political jurisprudence instead arise from the destabilisation of the relation between the political and the economic realms, from crises of democratic capitalism. This destabilisation changes, or threatens to change, the material constitution of social relations in a way that undermines the relative autonomy of the political. Although heightened in critical moments, this reflects a general tension, or 'disequilibrium', between the logics of democracy and capitalism, community and individualism, solidarity and

\footnotetext{
11 See C. Lefort, 'The Question of Democracy', Democracy and Political Theory D. Macey (trans.) (Cambridge, Polity Press, 1988) 9 -20.

12 See E. Christodoulidis, 'Total Market Thinking' (2015) German Law Journal. See also Minkinnen, this volume, on the 'totalitarianism' of modern capitalism.

13 Foundations, $461-465$.

14 Foundations, 462

15 The decisive theoretical figures, again, are Gauchet and Lefort, see Foundations, e.g. 48, 465.
} 
competition. This set of material dynamics is central to the process of political ordering that political jurisprudence reconstructs. ${ }^{16}$ Or so it will be argued.

The chapter proceeds as follows. First, I will explore the issue of the material foundation of Foundations by asking what grounds the autonomy of the political. This is elided by a focus on the secularisation thesis, but is thrown into sharper relief by Loughlin's later turn to Schmitt's reading of nomos (part 2). Second, I explore the possibility - suggested in the threefold order of nomos itself - that the autonomy of the political stands in complex, but internal relation, to material social reproduction, dependent on, but also threatened by the relative autonomy of the economic. Opening up the political-economic relation exposes the material dynamic of political ordering, driven by social and political struggles for equality (part 3). Next, moving to a diachronic register, I suggest that this relation can also provide a cogent account of the periodic crises of public law and the dynamic transformation, not only of government, but also of the state itself. This can only be touched on here, by examining first a critical period, the interwar breakdown of political order (part 4) and then a major realignment of the political-economic relation, the post-war reconstitution of the European state in the project of European integration, which now again enters a critical phase (part 5).

\section{WHAT GROUNDS THE AUTONOMY OF THE POLITICAL?}

The conceptual building blocks of Foundations coincide with the consolidation of the nation-state as a sovereign entity in a two-fold manner. Internally, it acquires the monopoly of legitimate force, based on secular foundations; in constitutional language, 'we, the people do solemnly ordain' our political and legal order. Externally, the nation-state is recognised as the only legitimate subject of international relations, with the right to decide on matters of war and peace, subject to conventions regarding civilised warfare, with a European 'balance of power' consolidated over a longer period, from the early modern nomos in the age of absolutism through to the 'golden age of the classical interstate system'. ${ }^{17}$

This is, of course, a simplification of a long and uneven historical process, but it crystallises a series of key conceptual distinctions: between international and

\footnotetext{
16 See e.g. Wolfgang Streeck, 'Taking Capitalism Seriously: Towards an Institutionalist Approach to Contemporary Political Economy' (2011) 9 Socio-Economic Review, 137 - 167. Loughlin tentatively explores a variation of this dynamic through the anthropological work of Christopher Boehm, but this naturalises hierarchy and domination and presents the state as essentially egalitarian, Foundations, 196 198.

${ }^{17}$ See B Teschke, 'Fatal Attraction: A Critique of Carl Schmitt's International Legal and Political Theory' (2011) 3 International Theory 179 - 227. Accordingly, the jus publicum europaeum implied a decisive rupture not only with divine right, but also with medieval just war theories, grounded in the moral universalism of the respublica christiana.
} 
domestic, public and private, state and society, the political and the social realms. ${ }^{18}$ It culminates in a distinct field of juristic thought, the German tradition of Staatslehre at the turn of the century, where the constitution of the state is based on a trinity of territory, ruling authority, and people. ${ }^{19}$ This begins its decline with the First World War and is radically problematised with the interwar breakdown of liberal constitutionalism and the collapse of the inter-state system, an interregnum that will be explored later in more detail.

But what are the material conditions for the grounding of these conceptual distinctions, as well as their eventual effacement? How do they appear in 'social-historical' perspective? On this, Loughlin appears ambiguous, particularly when Foundations is viewed alongside his other work.

Foundations itself suggests that the crucial rupture on which public law is built is immaterial: it is the autonomy-and primacy-of the political from the theological-spiritual domain that opens the space for the development of its key elements. This move is justified on the basis of Marcel Gauchet's 'secularisation thesis' - where modernity is characterized as a process of religious disenchantment and the rupture is signalled by the secularisation of the grounds of political authority. This is identified and embraced by Loughlin at the very outset of Foundations as essential to the project of public law understood as droit politique. ${ }^{20} \mathrm{It}$ is the rational, symbolic and ideal that plays the lead role in generating the modern constitutional dialectic presented in Foundations, albeit without any Hegelian terminus.

But on the character of the state itself, more than a merely symbolic reading is required in order to explain how the concept of the people 'can incorporate some sense of a collective body, conscious of its political existence and with the capacity for action.'21 Loughlin equivocates on the nature of this embodiment, drawing on Hans Lindahl's account of reflexive identity, and concluding that secular constitutional ordering is dynamic, never static. ${ }^{22}$ An existential unity, which 'presupposes a mysterious prior substantial equality of the people', is thus replaced with a less reductionist and more 'relational' reading of the normative power of the factual. ${ }^{23}$ His purpose is not to offer a new 'antinormativism' but rather to capture the dialectic of fact and norm in the course of constitutional development. ${ }^{24}$ This even leads the way to a (half-hearted) substitution of the Habermasian notion of the 'public sphere' for the concept of 'the state'. 25 Power then can be understood in fairly orthodox liberal fashion as

\footnotetext{
18 For Loughlin's own statement see e.g. 'Ten Tenets of Sovereignty', above.

19 See Foundations, 190-196.

20 Foundations, $6-7$.

21 Foundations, 224. Italics added.

22 Foundations, 226-7.

23 Foundations, 220 (Jellinek's phrase). See also, 'Constituent Power' in M Dowdle and M Wilkinson (eds.) Constitutionalism Beyond Liberalism (Cambridge, CUP, 2017).

24 Foundations, 220 - 221

25 Foundations, $228-231$.
} 
based on allegiance, or consent, and generated by open, responsible government, and even - although Loughlin is careful not to endorse it as such - the notion of discourse ethics and the aim (if never the realisation) of something approximating rational consensus. ${ }^{26}$

The Habermasian reading clearly leads where Loughlin is reluctant to follow, to an embrace of a liberal normativism, where the political project of constitution-building is a stepping stone to the constitution of a world society, albeit based on a multi-level configuration: domestic, regional, international. ${ }^{27}$ At a very basic level, the Habermasian notion of rational consensus would sit uncomfortably with Loughlin's insistence on the stubborn persistence of conflict in the human condition. But the broader problem, as I perceive it, is that reflexivity on its own does not and cannot account for the historical unity of the state, for its existence as a concrete political entity. It cannot account for 'the foundations of Foundations' at least not in anything other than a purely formal sense. In Lindahl's analytically informed enquiry the state is reduced to just one more formal mode of collective association (or self-representation), subject to the same paradoxical modalities as any other, rather than representing the dominant instantiation of modern political ordering. ${ }^{28}$ But the modern state for Loughlin is central to the foundations of public law.

Loughlin's later employment of the figure of nomos as developed by Carl Schmitt represents an attempt to firm up this ground. In this quite distinct perspective, public law is not founded primarily on the symbolic or the ideal, but on a nomos understood in its ancient, spatial, sense as a threefold 'concrete order', based on an original appropriation (nebmen), then distribution (or division) and finally production (or pasturage) of land. ${ }^{29}$ Together, this signifies the origins and source of the material constitution of political authority, sketched diachronically across three large-scale historical epochs. ${ }^{30}$ The jus publicum Europaeum is specifically grounded on the second phase of the nomos of the earth, coinciding with the maritime 'discoveries' made by European peoples and the overcoming of civil war internally. This early modern nomos, based on land appropriation, accrual of the monopoly of legitimate violence, and a claim to radical title overseas, underwrites the foundations of modern public law. It provides nothing less than

26 Foundations, 171, describing Habermas's route as 'contentious' but noting that 'by maintaining a distinction between the generative and distributive aspects of power and between the forms of power exhibited in potestas and potentia, his achievement is to have established an intellectual framework that is able to incorporate the specificities of political power'.

27 See J Habermas, The Postnational Constellation (Cambridge, Polity, 2001).

28 See H Lindahl, Fault-Lines of Globalisation (Oxford, OUP, 2014).

29 See M Loughlin, 'Nomos' in T Poole and D Dyzenhaus (eds) Theorists of Constitutional Crisis: Oakeshott, Hayek and Schmitt on Law, Liberty and State (Cambridge, CUP, 2015) and M. Loughlin, 'Politonomy', J Meierhenrich and O Simons (eds.) The Oxford Handbook of Carl Schmitt (Oxford, Oxford University Press, 2017) 570 - 592.

${ }^{30}$ It is interesting to note, as Schmitt does, commenting on its use in classical Greece, that nomoi and the Aristotelian notion of politiea could be created not only by land division but also by the liquidation of debt, see Nomos of the Earth, 68. 
the social historical conditions for the relative 'autonomy of the political', 'an expression of the constituent power to establish order'. ${ }^{31}$

Loughlin is candid about this process that begins with a 'land-grab'; the 'original sin' of constitutional ordering which remains at the foundations of public law. ${ }^{32}$ But, again following Lindahl, Loughlin gives it a reflexive twist: only in hindsight, once the second and third orders of nomos (of distribution and production) are established, can the original act be identified as having succeeded in laying foundations. Again, reflexivity on its own might be a philosophically intriguing way of out of a conceptual conundrum, but is substantively empty, flattening all instances of political ordering as if there were no specific form of the modern state in terms of the material organisation of distribution and production of resources in the economy.

The relation between the symbolic representation of the state inaugurated by the rupture of secularisation and the concrete form of the nomos in its material development is unclear. To complicate matters, there is in fact a trio of foundational elements that Loughlin develops, once we add in the significance of the concept of sovereignty and of the marks of sovereign power. ${ }^{33}$ Sovereignty stands as the representation of the autonomy of the political, which requires the state as its scheme of intelligibility and sovereign powers to effectuate any right to rule; but sovereignty is not integrated into the narrative arc of Foundations. Neither is the relation between the marks of sovereignty and concrete order explained in Loughlin's turn to nomos.

Nomos does, however, intriguingly suggest a new avenue of conceptualhistorical exploration for the adventures of the dialectic of political ordering - the material relation among the various orders of the nomos: appropriation, distribution and production. To put it differently, it throws open the dynamic of state origin and state transformation from the perspective of the evolution of political economy and material social relations, to which we can now directly turn.

\section{THE RELATION BETWEEN THE POLITICAL AND THE ECONOMIC IN THE MATERIAL ORDERING OF THE NOMOS}

The threefold concrete order of nomos suggests that the autonomy of the political does not (only) depend on the symbolic process of religious disenchantment. It also suggests a more complex and dynamic ground than the act of territorial

\footnotetext{
31 See Loughlin, 'Nomos', above.

32 ibid. The connection of nomos with violence is one reason for Arendt's ambivalence about the concept, and ultimate preference for the Roman lex, which is suggestive of a more dynamic, relational and less absolutist conception of origins. For discussion, see M Wilkinson, 'Between Freedom and Law: Hannah Arendt on the Burden of the Tradition' in Goldoni and MacCorkindale (eds) Hannah Arendt and the Law (Oxford, Hart Publishing, 2012).

33 See e.g. M Loughlin, 'Sovereignty', chapter 5 of The idea of Public Law (Oxford, OUP, 2003)
} 
appropriation alone; a process that integrates the material organisation of distributive and productive forces and social relations, the second and third orders of nomos.

But appropriation, distribution and production operate within a capitalist economy according to an internal logic of their own, and one that exists in an uneasy relation with the autonomy of the political realm. This relation between political and economic logics as a feature of nomos is captured by an extension of Rosa Luxemburg's characterisation of the process of imperialist Land-nabme as signifying not only literal 'land-grabbing' ('simple robbery' as Arendt calls it) but also metaphorical market expansion, integrating spatial accumulation with increasingly intense processes of commodification.

Luxemburg's insight suggests a political-economic reconstruction of the threefold order of nomos, as well as a related, but distinct, periodisation in contrast to Schmitt's. ${ }^{34}$ The changing character of nomos reflects the transformation of the state from a feudal to a capitalist and later to an imperial organisation of political and economic power; 35 and even to postmodern types of state power that have emerged in the more recent period of informal American empire and economic neo-liberalism. ${ }^{36}$

The process of political ordering and state development can then be internally related (but not reduced) to the logic of capitalist social relations. Political ordering operates not just on the initial - or subsequent - forceful accumulation, concentration and protection of land (or property), but on a continual transformation of social relations, setting in train distinctive imperatives of competition, profit-maximisation, the compulsion to reinvest surpluses, and the need to improve labour productivity by developing the forces of production. ${ }^{37} \mathrm{It}$ is not only original or 'primitive' accumulation (or 'appropriation') that sets up the economic and social conditions for the market, as Smith, Marx and Weber note, ${ }^{38}$ but also the periodical re-constitution of these conditions through 'accumulation by dispossession' (through re-distribution and re-production of resources by political means). ${ }^{39}$ Social relations are transformed through direct and indirect

\footnotetext{
34 See R Luxemburg, The Accumulation of Capital (London, Routledge, 2013 [1913]).

35 Arendt's endorsement of Rosa Luxemburg's 'brilliant insight into the political structure of imperialism' (Origins of Totalitarianism, 148) is interesting because Arendt, like Schmitt, tries to retrieve the Greek idea of nomos. Although Schmitt omits discussion of Luxemburg's updating of Marxism for the imperial age, he does, briefly, address Marx's idea of original appropriation in Nomos of the Earth, 333- 334. He adds, 'if the essence of imperialism lies in the precedence of appropriation before distribution and production, then a doctrine such as expropriation of the expropriators is obviously the strongest imperialism, because it is the most modern' 334.

36 See L Panitch and S Gindin, The Making of Global Capitalism: The Political Economy of American Empire

(London: Verso, 2012). For an exploration of the recent continuation of capitalist land-grabbing, see e.g. F. Jamieson, 'Aesthetics of Singularity' (2015) New Left Review.

${ }^{37}$ E Wood, 'Logics of Power: A Conversation with David Harvey', (2006) Historical Materialism 19 - 20.

38 The identification of coercive forms of appropriation - whether through domestic corruption, war, or in forms of global imperialism ('political capitalism') - as central to the formation of the modern state is stressed by Max Weber. See e.g. R Swedberg, Max Weber and the Idea of Economic Sociology (1998) 46 - 53.

39 See D Harvey, The New Imperialism (Oxford: OUP, 2003) 36.
} 
forms of intervention which function to commodify and marketise, impose competitiveness, austerity or privatisation, or shift private into public debt, and so on. The extent to which these processes can still usefully be categorised on the basis of traditional class analysis is moot, but the class pedigree of nomos can hardly be doubted. As Brunkhorst bluntly puts it, 'no nomos without class rule', ${ }^{40}$ a feature of nomos also noted right at its root by Aristotle. ${ }^{41}$

The autonomy of the political from the economic is thus a dynamic, twosided affair, rather than the one-off rupture from religion sealed by the event of secularisation..$^{42}$ To keep both sides in sight has the advantage of thrusting into view the consequences for political ordering of the relative autonomy of the economic, which contemporaneously evolves in the modern state. This reveals the state 'from the other side', as it were. These are not parallel developments but interlinked; the state might be said to encompass the 'unity in difference' of these two faces of the political and the economic, public and private. In other words, the state, if viewed not only as a secular but as a capitalist formation, is one in which the economy (comprising taking, distributing and producing) is relatively autonomous from the political, paradigmatically expressed in classical as well as newer forms of liberalism in the idea of the self-regulating market, the myth of the invisible hand, the sanctity of debt, conditions of perfect competition etc. This develops its own set of legal couplings, with property rights, contractual obligations, formal equality of status, emerging in the constitution of the modern state and state-system. As a dynamic, it tracks the transformation of social relations of reciprocity and solidarity into what Hayek would later call 'catallactic relations': relations of exchange, based on competition and self-interest. Within this realm, inequality is legitimated, justified, or naturalised. It is, in any case, 'privatised' and depoliticised. 43

It is notable that it is not only Marxist and critical political-economic lines that are missing from Loughlin's account of the dynamic of political ordering. Foundations' own conceptual categories are never placed in relation with the tradition of classical, neo-classical, ordoliberal or neo-liberal thought that insists on naturalising or insulating the 'laws' of the private, market sphere, beginning from Locke, Smith and Paine but continuing in prominence in the post-war era with the group associated with the Mont Pelerin Society. ${ }^{44}$ The figure of John Locke, who arguably grounds this more substantive material account of the modern state (but

\footnotetext{
40 Brunkhorst, this volume.

${ }^{41}$ For Aristotle, 'the rule of nomos means the rule of the middle classes as opposed to the rule of the very rich, on the one hand, and the rule of the masses or the poor, on the other', cited in Schmitt, above, The Nomos of the Earth.

42 Whether or not this is, in fact, such a neat and singular rupture is debatable, but need not be explored here. See Bomhoff, this volume, for some doubts.

43 According to Wood, 'Capitalism alone has created an autonomously economic form of domination', in 'Logics of Power', above, 13.

44 See P Mirowski, The Road from Mont Pelerin: The Making of the Neo-Liberal Thought Collective (Harvard University Press, 2009).
} 
from a classical liberal perspective, based on individual property rights, and a labour theory of ownership) is conspicuous by his absence in Foundations, featuring only in regard to his influence on modern understandings of the prerogative power. ${ }^{45}$

Loughlin, unlike Schmitt (or in different ways Hayek or Oakeshott) does not aim to defend a liberal (bourgeois) Rechtsstaat against the perceived encroachments of political social democracy.46 Political jurisprudence is thus resistant to the Marxist critique (as well as the liberal defence) of political economy to the extent that its aim is not to defend an illusive bourgeois order, but to account for political order as such, which only contingently depends on the workings of a liberal rule of law. The politically disruptive potential of an autonomous civil society is also alluded to by Loughlin, albeit rather in passing, when taking note of Hegel's reconstruction, where the market, if left to its own devices, would paradoxically tend to increase the need for government, as it would exacerbate existing inequalities that would then need to be tempered through political means. ${ }^{47}$ Hegel's concern for the tendency of bourgeoisie society towards inequality and, therefore, instability due to its tendency towards over-accumulation at one end and deprivation at the other is captured in his notion of the 'rabble', a problem of the dispossessed (as well as the ultra-wealthy) that is produced by industrial capitalism. ${ }^{48}$ Although it is one to which Hegel offers no satisfactory solution, he captures the nature of the problem, unlike later liberals.

And yet, for Loughlin, as for Hegel, this problem of inequality - to the limited degree it is addressed - is presented entirely from the 'top-down'. It is presented in terms of governing potentia (the capacity to rule) rather than in its dynamic with potestas (the right to rule). Potentia emerges as a managerial, top-down activity of government rather than a bottom-up struggle for equal rights taking place in civil society through social movements and political parties, mediating the balance between public goods and private interests. ${ }^{49}$ Material relations are relegated to a technical, administrative machinery of governing in the interest of the salus populi - a term which itself flattens out material inequalities, and the continuous oscillation between public and private power. The dynamic of potentia is not rejoined to its roots as collective power to but restricted to this question of

\footnotetext{
45 Foundations, $383-387$.

46 Perry Anderson, in a masterful essay, groups Schmitt, Hayek and Oakeshott, along with Strauss, as the 'Intransigent Right' of the twentieth century, see P Anderson, 'The Intransigent Right at the End of the Century' (1992) London Review of Books.

47 Foundations, $349-350$.

48 See F Ruda, Hegel's Rabble: An Investigation into Hegel's Philosophy of Right (London, Bloomsbury, 2011).

${ }^{49}$ Although Loughlin makes brief reference to Mortati's emphasis on political parties (Foundations 397), as Brunkhorst puts it: 'the alternative version of potentia that he had distinguished in Chapter 6 on 'Political Jurisprudence'... characterised... as 'power to' (with Arendt and Habermas), as distinct from 'power over' (Mann, Foucault) and which is "rooted in the intersubjective generation of solidarity" is gradually lost in later chapters.' (Brunkhorst, this volume)
} 
mechanical capacity, despite Loughlin having the resources to reunite it with the more emancipatory traditions that draw from Spinoza. ${ }^{50}$

The dialectic of capacity and right to rule (the 'capacity-right nexus', as Loughlin now calls it) tracks the relation between the political and the economic not only as a question of governmental power, but also of state (and inter-state) formation..$^{51}$ This is because the constitution of political power - in its relation to the economy and vice versa - goes to the question of the governing relationship and the set of beliefs on which it rests. In Loughlin's own terminology, material relations go to the question of potestas and the relation between potestas and potentia.

This is not to deny, of course, that material relations are, to a large extent, 'managed' through governmentality as Loughlin argues, but this view alone misses the significance of social movements, political parties, geo-political currents and interpersonal social relations in the dynamic of political ordering and disordering. These are material forces which constitute and reconstitute beliefs about the ruling relationship and about the nature of the demos itself. The idea of equal political liberty, a principle apparently central to, but insufficiently articulated in 'political jurisprudence', does not transpire as a moment of symbolic or normative revelation, but unfolds over time; it attracts a different meaning over time through democratic movements of solidarity and emancipation as well as capitalist movements of competition and domination.

The Enlightenment trinity of 'liberty, equality and fraternity' rather loses it third component for the major part of Foundations - until it re-appears through the work of Duguit and his functionalist notion of 'social solidarity'. But it is disarmed of any radical potential. Solidarity is merely a fact of social life in this account, losing any emancipatory political quality, divorced from any class or other struggles against injustice, domination or exploitation. The project of egalitarian solidarity, as Brunkhorst puts it, which emerges from the bottom up as communicative 'power to' (as a feature of the dialectic of potentia/potestas), is elided in Foundations. These movements may well have a functional element, but it is hard to see how functionality would guarantee the necessary equilibrium, short of a strong, and perhaps improbable, social-biological evolutionary thesis.

For Loughlin, according to his brief anthropological reconstruction, the egalitarian impulse comes, if at all, from the state, in contrast to the natural inequalities of man. ${ }^{52} \mathrm{By}$ marginalising the problem of inequality, delegating it to a discrete domain of anthropological enquiry, and by presupposing the relative autonomy of the political from the economic, rather than reconstructing it and problematising its social-historical development, Loughlin's account is deprived of a crucial aspect if not the key to conceptualising the material tensions inherent in the actual dynamic of political ordering and - crucially, of disordering.

\footnotetext{
50 See e.g. M Hardt and A Negri, Empire (Cambridge, MA: Harvard University Press, 2000).

51 See now M Loughlin, 'Erosion of Sovereignty' (2017) Netherlands Journal of Legal Philosophy

52 See Foundations, 197 - 198.
} 
The broader point is that the political is only relatively autonomous from the material composition of society. Material inequalities are not hermetically sealed off or fully separated from the political. They pose a challenge not just to the necessary stability of the governing arrangements but to the maintenance of the political equality on which the autonomy of the political depends, not least because of the potential of a hegemonic bloc or idea to dominate or even determine the activity and structure of political ordering, or erode politics altogether. It should be recalled that the empty place of power depends on a political indeterminacy that can only be guaranteed by the praxis of democratic struggle. It is achieved, or rather is achievable (since it must be viewed as ongoing), through contesting the heteronomy of the market, the alienation of class rule, the domination of cultural hierarchy, the subjugation of imperialist coercion. These struggles are abstract tussles over the meaning of concepts such as freedom and equality, as well as material contests over power and resources, involving persuasion, solidarity and often force.

Loughlin's metaphor of 'grammar', like the concept of 'reflexivity', is too formal a notion to account for these dynamics and the emergence of competing and collective subjects in conditions of inequality. ${ }^{53}$ This deficiency is common to the line of thinking that is so central in Loughlin's reconstruction of political order, from Hobbes through to Schmitt. The Hobbesian-Schmittian foregrounding of a ruling relation of 'protection and obedience' (despite their differences) elides social relations of domination as well as those acts of resistance against them that shape the quality of political order. Both aim to overcome natural hierarchy, in Hobbes's case by supposing rough equality between persons, in Schmitt's account by employing the concept of homogeneity. But in so doing they naturalise social hierarchies and inequalities of wealth and resources, by projecting as a state of nature or as the basic political binary (friend/enemy) what is, in fact, a social state of conflict.

Political jurisprudence makes a similar move, flattening out social relations with the concept of 'political unity', however reflexive a twist this is given. Without any account of the material struggle for and over the autonomy of the political - from a dominant economic class, geo-political formations or from 'economism' more generally - the autonomy of the political becomes substantively less rich, and, if secularisation is considered to be a fait accompli, ultimately empty.

At this point, we can bring the democratic character of the modern state more sharply into view. This is not merely a normative issue. The relevant problem posed by modern democracy is primarily material in nature. It is that the democratic dynamic historically (naturally?) expands and extends the demand for material goods, and for relative material equality, calling for redistribution or changes in the conditions of production. As individuals, groups and classes strive for political emancipation in the struggle for universal franchise, for basic political

53 See also Goldoni, this volume. 
equality, (workers movements, women's movements, post-colonial movements etc.) their demands place exacting material burdens on the governing arrangements of the state as well changing the basic ideas of collective autonomy. These are not only political struggles narrowly conceived, but struggles for the transformation of material social relations, for 'effective autonomy', or for us to will the means to our collective autonomy, as Castoriadis puts it. ${ }^{54}$

These struggles face obstacles, first, to be pursued in a way which respects other constitutional principles associated with the advance of liberal ideas of good government, historically with the liberal rule of law (or bourgeois Rechtsstaat). The political-economic relation exposes how positive public law can come into conflict with various imperatives of governmentality, which are themselves directed and conditioned by social and political contest. The relationship between state and society, the political and the economic, is thus mediated not only by governmental policy but by a liberal order which guarantees the conditions for market autonomy in an apparently 'neutral' manner; private property relations, intellectual property guarantees, freedom of contract, conditions of free competition and so on.

Over the course of the 'short twentieth century', as democracy increasingly makes it mark as a material force, the political-economic relationship is also mediated by the imperatives of the sozial Rechtsstaat, making public matters such as welfare, social rights and industrial relations, in an attempt to balance or remedy the harsh and potentially disruptive consequences of market society.

But these democratic material demands are not placed within a vacuum, but face the counter-pressure of a capitalist dynamic (whether framed as a hegemonic class or bloc or as a representation of 'market justice'), generated by the capacity of a capitalist class to affect the political process, to threaten to transfer wealth, withhold or avoid tax, and utilise the conservative machinery of the very same liberal legal system to refuse or obstruct structural change to the political-economic relation. As Wolfgang Streeck puts it, the modern state has to maintain an equilibrium between the Staatsvolk and the Marktvolk that is increasingly in tension. ${ }^{55}$ This is explainable on the basis of the contradictory tendencies of democratic capitalism itself - but this explanation is not open to Loughlin because of his focus on the imaginary on the one side, and the managerial on the other. At root, it is because of his avoidance of any investigation into the modern state as a democratic and/or capitalist state, which is the material form that the political-economic relation takes in modernity.

\footnotetext{
${ }^{54}$ See C Castoriadis, Philosophy, Politics, Autonomy: Essays in Political Philosophy tr. D. Ames (Oxford

University Press, 1991). Cf. Penner's chapter in this volume.

55 See W Streeck, Buying Time: The Delayed Crisis of Democratic Capitalism (London: Verso, 2014)
} 


\section{THE INTERWAR BREAKDOWN OF PUBLIC LAW: A CRISIS OF THE STATE AND NOT JUST OF GOVERNMENT}

From a material perspective, the autonomy of the political is a fragile, ambiguous and even illusive achievement, rather than a one-off creation of the modern world, 'born of the deepest ever fracture in history'. ${ }^{56}$ Once the autonomy of the political is placed in dialectical relation with the autonomy of the economic, the political state with the market state, the material constitution of order and disorder can be explored and with it the fragility of public law. This cannot be bracketed as relevant only in the exceptional situation when 'extreme inequality' or a tumultuous rabble makes its presence felt as a political irritant; it is intrinsic to the ebb and flow of state transformation, if making its mark most clearly in conjunctural moments.

This precarious process of political ordering reaches breaking point in the interwar years, and now returns if not (yet) with quite the same intensity in the current crises of democratic capitalism, presented acutely in the recent Euro-crisis, but reflected elsewhere. The later set of events of course largely postdates Foundations. But it will be suggested here that a diachronic analysis of interwar Europe and post-war reconstruction offers an account of the heightened tension and collapse followed by a basic re-ordering of the political-economic relation crucial to the transformation of public law in the twentieth century.

It is curious that neither the interwar breakdown of political ordering nor its post-war reconstruction is given much attention in Foundations, or indeed in Loughlin's later turn to explore the concept of nomos. And it is a disconcerting feature of the narrative of Foundations that recent developments such as those associated with the 'triumph of the social' get blurred into Duguit's work from the 1920 's, skipping the 'short twentieth century' in between.

In the interwar period, the key distinctions on which Foundations builds are put under severe stress - between interstate and domestic, between state and society, public and private, potestas and potentia. The myth of the state of the 'long $19^{\text {th }}$ century' and the order it represented faced extreme pressures, an order in crisis if not in terminal decline. ${ }^{57}$ The problem for an approach to political ordering which prioritises nomos as land appropriation in this context is apparent; Schmitt himself considered the modern jus publicum Europaeum to have been displaced, because land was no longer the 'clear-cut ground for political and economic organisation', even though political and legal thinking remained mired in the 'older elemental presuppositions'. ${ }^{58}$

The second phase of the nomos of the jus publicum Europeaum had reached its end game with the First World War. Schmitt would later speculate that the

\footnotetext{
56 Foundations, 7, citing Gauchet.

${ }^{57}$ B Teschke, 'Fatal Attraction', above, 187

58 G Balakrishnan, 'Geopolitics of Separation' (2012) New Left Review, 68
} 
chaos brought about with the end of British Empire and the disintegration of the inter-state Westphalian order it loosely underwrote could only properly be resolved if the world was reorganised into continental blocks underpinned by large-scale transnational economic orders. When German hegemony failed to materialise, Schmitt turned his attention to the emerging American empire with its liberal universalist ideology and the technical means to extend its global influence, including control of air power. As Loughlin himself puts it: 'in place of European powers determining the spatial order of the world, during the $20^{\text {th }}$ century the world determined the spatial order of Europe', a reversal that signals a new stage in the evolution of the nomos of the Earth. ${ }^{59}$

But rather than merely signifying geo-elemental or geo-political shifts, the interwar breakdown of political order and its post-war resettlement must be reconstructed on the basis of the political-economic relation in terms of the tension between democracy and capitalism. Without discounting the importance of regional and global re-orientations, it is the threat posed by democracy and capitalism as real social forces that threatens to disrupt the political-economic relation in a way that is salient for political jurisprudence.

All that can be offered here is a brief and stylised reconstruction of this interregnum. There is, of course, a much longer background dynamic involved. The conservative fear of popular emancipation is presaged in an earlier epoch; evident from Marx's critique of Hegel's Philosophy of Right and the 'democratic revolutions' of 1871, and 1848, and even earlier with the Rousseauvian influence on the Jacobins. ${ }^{60}$ But for interwar conservative liberals, such as Schmitt, the question of how the process of democratisation could be made safe for liberal economics had become immediately pressing for domestic political reasons (allied to the threat posed by the Bolshevik revolution).

Interwar pressure on the established political-economic relation of classical liberalism comes from two directions - from unfettered market power leading to monopoly capitalism and ultimately Fascist dictatorship on the one hand, and from unfettered democracy leading to socialism, common ownership of the means of production and the loss of the relative autonomy of the economic on the other. Both threaten the normal workings of distribution and production in the liberal market economy, threatening to fundamentally reshape the relation between the political and the economic of the 'long 19th century'. The threat to the old political order emerged, in other words, in relation to internal as much as external 'enemies' of the existing state and state-system of the jus publicum Europeaum.

Political equality - hitherto merely a formal presupposition of liberal social contract theory - becomes materially significant in the interwar period both as a

\footnotetext{
${ }^{59}$ Loughlin, 'Nomos', above.

${ }^{60}$ See e.g. M Goldoni, 'Rousseau's Radical Constitutionalism and its Legacy' in M Dowdle and M Wilkinson (eds.) Constitutionalism Beyond Liberalism (Cambridge, CUP, 2017).
} 
force of social and economic change, and as a new basis for claims of legitimate authority. This is a general phenomenon, but a focus on Weimar Germany sharpens the issues. As a social force, democracy is liberated and strengthened through the grant of universal suffrage (guaranteed for the first time in German history by the Weimar constitution itself), and by intense party politics and parliamentary democracy, the rise of local and regional claims to autonomy, including worker's councils and other movements of economic democracy.

For Schmitt, the welfare state, the 'quantitatively total state', colonised by interest groups and associations, would be a deformation of the classic liberal 'neutral state' of the 19th century.61 Actually existing pluralism, seen through Hobbesian eyes, was one step away from a condition of civil war within which there would be no judge to determine 'mine' and 'thine', threatening the disintegration of bourgeois society. ${ }^{62}$

The emancipatory potential of class-consciousness combined with universal suffrage raised the possibility for full political control over the economy - threatening the balance between the political and the economic and precipitating a crisis of political ordering and of public law itself. As an ideological matter, democracy becomes increasingly central to constitutional theory through the linking of legitimate authority with democratic procedure (coincident with the associated rise of legal positivism). ${ }^{63}$

All were subject to Schmitt's fierce polemic. But above all, it was social democracy that threatened his position because it called into question not only how socio-economic conflicts should be mediated through structures of 'government' (potentia) but the basic relationship of state and society, central to the established category of the right to rule (potestas). The very idea of the General Will - which eliminates the right of resistance in classical social contract thought became threatening with the politically active population no longer a discreet and homogenous male bourgeoisie. The problem that democratic emancipation and class struggle posed for the politically conservative and economically liberal Schmitt was apparent: 'in a democratic age it was entirely possible that a legislature based on universal suffrage could chip away at the rules of property and contract which regulate the intercourse of bourgeoisie society.' ${ }^{64}$ It threatened the governing relationship, the remodelling of the idea of the political order of the state and of the people who constituted it. What for Sieyes' was the 'third estate',

${ }^{61}$ See K Tribe, Strategies of Economic Order: German Economic Discourse 1750 - 1950 (Cambridge, Cambridge University Press, 1995) $179-180$.

62 G Balakrishnan, The Enemy: An Intellectual Portrait of Carl Schmitt (London, Verso, 2002) 124. 'In Schmitt's view' Balakrishnan notes, 'the polycratic, corporatist, welfare state threatened the existence of the state as a higher power standing above society, or even as a neutral power standing impartially between the major social classes' (at 104).

${ }^{63} \mathrm{Schmitt}$ thus considered authoritarianism a necessary antidote both to the fragmentary processes of democratisation and pluralisation, which were weakening the German state and endangering its Constitution, and to the relativism of a legal positivism without substance, personified in the figure of Hans Kelsen and his Pure Theory of Law.

${ }^{64} \mathrm{G}$ Balakrishnan, The Enemy, 98 
which was nothing and shall become everything, potentially becomes the working class. This was Schmitt's fear:

Now the proletariat becomes the people, because it is the bearer of this negativity. It is the part of the population which does not have property, does not participate in the productive majority, and finds no place in the existing order... Democracy becomes a proletarian democracy, and eliminates the liberalism of the propertied and educated bourgeoisie. ${ }^{65}$

How could the normal political-economic relation be protected or reinvented in the political turbulence of late Weimar? For Schmitt, as for many other conservatives (with the notable exception of Austrian economic liberals), it was impossible to envisage any straightforward return to laissez-faire, a 'night watchman state' in the vein of Hayek and other conservative liberals and later libertarians across the Atlantic; the restoration of the relationship between the political and economic could be achieved only with a temporary (or more permanent) suspension of legal order by commissarial dictatorship, violating the separation between politics and economics in order to restore it. If the democratic movement of the autonomy of the political threatened the capitalist state (viz. the relative autonomy of the economic), then militant protection was required to defeat it. What was required was, in his view, an authoritarian state.

The significance of this new authoritarianism is apparent in Schmitt's address in November 1932 to an association of German industrialists, the Langnam Verein: 'Strong state, free economy', ${ }^{6}$ in which he advocates a robust autonomous economic order, as a third category in addition to and separate from the state and the individual entrepreneur (or 'private sphere'). ${ }^{67}$ In this model, economics must become neither totally politicised, as recommended by social democrats, nor totally privatised, as urged in classical liberalism. But above all, it must not be subject to the forces of democracy.

Hermann Heller, Schmitt's social democratic protagonist in late Weimar, saw with great clarity the authoritarian nature of the political formation that Schmitt was defending. To grasp its full significance, a reaction to the inherent instability of political order in a society that is both democratic and capitalist, Heller takes a longer-view of the ebbs and flows of $19^{\text {th }}$ and early $20^{\text {th }}$ century

\footnotetext{
${ }^{65}$ C Schmitt, Constitutional Theory, tr. J Seitzer (Durham, NC, Duke university Press, 2008) 271- 272.

${ }^{66}$ Se R Cristi, Carl Schmitt and Authoritarian Liberalism: Strong State, Free Economy (University of Wales Press, 1998). Schmitt permitted its reprinting at least twice, suggesting for W Scheuerman that it was a text that was of some significance to him, see Carl Schmitt and the End of Law (Rowman and Littlefield, 1999) 288.

67 The demand for autonomous economic administration would complement and overlap the third form of institutional juristic thought he was concurrently developing, based on concrete order, influenced by French jurist, Hauriou. See K Jayasuriya, 'Globalisation, Sovereignty and the Rule of Law: From Political to Economic Constitutionalism’ (2001) 8 Constellations 442 - 460.
} 
liberalism, and its strange mutation into a form of 'conservative liberalism'. ${ }^{68}$ In the $19^{\text {th }}$ century, the conservative, reactionary forces protecting the feudal order had put up fierce, if uneven, resistance to the pressures of liberalism and capitalist modernisation. Although largely unsuccessful, not all their efforts went unrewarded, as conservatives managed to inculcate into the bourgeoisie political sensibilities that produced a 'peculiar feudal capitalist inter-breeding', labelled 'national liberalism'. The reverse process was now taking place, in Heller's view, as the forces of conservatism were marshalled in defence of liberal capitalism and against any forms of solidarity. 'Matching this sociological transformation, the "authoritarian" state represents a further development of national liberalism. Most appropriately it is, Heller concludes, 'to be addressed as authoritarian liberalism'. ${ }^{69}$

The designation of the political order is justified in Heller's view because of its position vis-à-vis the 'cardinal problem' of the present, 'the question of the economic order', prescribing, as it does, a strict separation of politics and the economy. Mutual bonds, rather than being urged to resist the pressures of liberal modernisation, must now be 'loosened', at least regarding socio-economic matters. ${ }^{70}$ The primary object of the authoritarian liberals was the elimination of social democracy from politics and the defence of an autonomous economic sphere, not through laissez-faire, but through intervention.

Loughlin's insistence on neutralising Heller, suggesting that he adopted a 'highly abstract' conception of constituent power, is puzzling. ${ }^{71}$ It is not only that this elides Heller's active part in the German Social Democratic Party as antagonist of Schmitt, which is clearly at the surface of his political writings in Weimar; it is that these commitments are essential in Heller's view for stabilising the constitutional dialectic itself. In an era of actual democracy, with full participation, the material prospect of socio-economic equality in addition to the symbolic integration of society is required for the constitutional state to function, to obtain enduring political legitimacy; in its absence, the tendency will be to turn to authoritarian alternatives, whether of Left or Right.

For the process of political ordering in a democracy there must be some prospect of substantive equality 'between rulers and ruled', even though Heller doubts that this can ever be truly and finally achieved, because the social structure

\footnotetext{
${ }^{68}$ H Heller, 'Authoritarian Liberalism’ tr. from 1932 (2015) European Law Journal.

69 ibid

${ }^{70}$ Ibid.

${ }^{71}$ See M Loughlin, 'On Constituent Power' in Dowdle and Wilkinson (eds.) above, 170. Loughlin is not alone in marginalising Heller's substantive commitments. Dyzenhaus makes the same move in his book on Heller, Schmitt and Kelsen, underplaying both Schmitt's economic liberalism and Heller's democratic socialism, see D Dyzenhaus, Legality and Legitimacy: Carl Schmitt, Hans Kelsen and Hermman Heller in Weimar (Oxford, OUP, 1997). The problem with this move has been noted elsewhere, see e.g. C. Thornhill, 'Carl Schmitt After the Deluge' (2000) History of European Ideas 225 - 264. It is at the same time a great strength, and a weakness, of Foundations that it so strenuously avoids questions of politics.
} 
is 'necessarily antagonistic'. ${ }^{72}$ This antagonism, for Heller, is fully material in nature due to the dynamics of a capitalist economy. But in Heller's vision, material inequality is ultimately fatal to political order: the prospect at least of relative socio-economic equality is required for the stability of the governing relation. It is for political democracy to work this through peacefully, with the aid of political parties, who are able to unite a multitude of wills into a singular voice.

To refocus political ordering with a view to its broader reintegration with political economy and the issue of inequality, we can turn to the work of Karl Polanyi, whose account of the great transformation of industrial capitalism, and the resulting political and social reaction to its dis-embedding of social relations mirrors Heller's own reflections and over the longue durée.

In Polanyi's account, the modern nation-state exists and evolves in dialectical relation with the modern market economy. ${ }^{73}$ If the modern nation-state operates according to a logic of political equality and solidarity, the modern market economy functions on the basis of material inequality and competition. These two distinct logics exist in a perpetual tension, captured by the Polanyian figure of the 'market society'. The commodification of the 'fictitious commodities' of land, money and labour (dis-embedding that which must remain embedded in society) thus produces a reaction, when society tries to protect itself from the harsh consequences of marketisation, a reaction which may be spontaneous as well as organised. The form this response takes varies greatly depending on the strength of the democratic culture of the society - where this has been hollowed out by forms of authoritarianism, and where spontaneous reaction has been obstructed by political power, society may be too weak to prevent an eventual extreme response. This explains the interwar breakdown of liberal constitutionalism, when forced economic liberalisation and rigid adherence to austerity ultimately produces a 'double movement' of dramatic social and ultimately political reactions.

Polanyi notes how this dialectic plays out in geopolitical as well as domestic relations; politics could be made submissive to the economy by external constraints on the democratic process. Particularly significant in Polanyi's account, is the attempt in the 1920's to restore the Gold Standard, submitting politics to an overwhelming 'economic rationality', in an attempt to protect currency stability. ${ }^{74}$ It was no coincidence, for Polanyi, that those countries which extricated themselves from Gold, regaining monetary control, and their status as 'masters not servants of the currency', 75 were better able to respond to economic

\footnotetext{
${ }^{72} \mathrm{H}$ Heller, 'Political Democracy and Social Homogeneity' from A Jacobson and B Schlink (eds.) Weimar: A Jurisprudence of Crisis (University of California Press, 2002) 257. The dialectic of fact and norm is, in a democracy more than elsewhere, dependent on, and shaped by 'social equalisation', Heller, above, 261.

${ }^{73}$ K Polanyi, The Great Transformation: The Political and Economic Origins of Our Time (Boston, Beacon Press, 2001 (1944)).

74 Ibid, at 236

75 ibid, 242
} 
circumstances, to rebalance social relations without departing from the essence of liberal democratic politics. ${ }^{76}$

To return to Loughlin's nomos, there is a suggestive analogy between Polanyi's three 'fictitious commodities' - land, money and labour - and the threefold ordering of nomos: appropriation, distribution and production. It suggests that the autonomy of the political depends on maintaining democratic control over these 'non-commodities', or at least the political capacity to condition society against market forces and the capitalist economic logic of accumulation, distribution and production that acts upon them. The interwar interregnum specifically shows that the process of political ordering hinges on a politicaleconomic relation that is in a delicate balance between the antagonist material forces of capitalism and democracy and that public law is subject to the vagaries of this conflict as well as marking its shifting boundaries.

\section{THE TRANSFORMATION OF THE STATE, NOT JUST THE GOVERNMENT: POTESTAS IN THE POST-WAR CONSTITUTIONAL IMAGINATION}

But could the democratic capitalist state - the relative autonomy of the political and of the economic - be restored in the post-war period if instead of democratisation, institutions were turned towards ensuring the economic sphere functioned on the basis of free competition? If the focus of public law shifted to securing equality in the marketplace, preventing monopolies and cartels, and ensuring economic freedom, might Heller's and Polanyi's lessons, and the democratic struggles for material equality, be forgotten?

Schmitt's motto of the 'free economy' requiring the 'strong state' - the maintenance of the material conditions of the bourgeois Rechtsstaat - would be taken up and reformulated by the Freiberg ordoliberals. They, unlike Schmitt, were concerned as much with the perceived dangers of monopoly capitalism as with socialism, ${ }^{77}$ fearing the impact of monopolisation and cartelisation on economic freedom as much as the 'irrationality' of social democracy. The ordoliberals were more consistent than Schmitt, taking note of the threat to political order from the other side, as it were, from the dysfunctionality of capitalist logic in a relatively

\footnotetext{
76 According to Polanyi, the political dispossession of Wall Street by going off gold (Roosevelt did so almost immediately on gaining power in 1933) was the key to preventing the occurrence in the US of a 'social catastrophe of the continental type', ibid, 238.

77 On the links between authoritarian liberalism, Carl Schmitt, and ordoliberalism, see W Bonefeld, 'Freedom and the Strong State: On Ordoliberalism (2011) New Political Economy. It was Franz Neumann's classic text on National Socialism, Behemoth, published in 1941 that described National Socialism as 'Totalitarian Monopoly Capitalism' and Neumann who, long before ordoliberalism, had already doubted whether the legal institutions of capitalist economy can perform their functions where the market is subordinated to the power of monopolists, developing the idea of an 'Economic Constitution' to counter this. For discussion, see K Tribe, above, 174.
} 
autonomous economy. From their perspective, the strong state had to be equipped with independent institutions capable of intervening if necessary to ensure the conditions of fair competition and a free market. The ordoliberals made a new attempt at a differentiation of politics and economics based on the political decision for a liberal economic order, backed by constitutional guarantees and institutional protections. The free market machine does not run itself; once started it requires constant oiling through the supervisory mechanisms of the state.

But this was not a vision of a vibrant democratic state. In the jargon of post-war European reconstruction, it was 'restrained democracy' (a post-war reflection of the inappositely named 'militant democracy'), ${ }^{78}$ encapsulated in the story of West German post-war constitutional development: 'we are (afraid of) the people'. ${ }^{79}$

This vision goes, not only to the functional question of governmental powers, but to the very idea of the governing relationship, of the nature and limits of the right to rule over the economy. Indeed, the ideological and constitutional significance of ordoliberalism is identified as early as 1955, with Carl Joachim Friedrich noting that it signals a fundamental re-ordering of the basic ideas underpinning constitutional theory. ${ }^{80}$ As Friedrich understood, and as Foucault would later explore in his lectures on neo-liberal governmentality in 1979, the decisive theoretical turn triggered by ordoliberalism had been to replace constituent power (or popular sovereignty) with individual economic freedom - a freedom to participate in the market — as the legitimating device for the whole constitutional order. ${ }^{81}$

If to put the law above man, as Rousseau quipped, 'il faudrait des dieux' (one would need Gods), the ordoliberals answered the call for a new set of elites, who, confounding Rousseau, could, like Gods, finally 'give laws to men'. ${ }^{82}$ The means to achieve this was a new understanding of economic constitutionalism, protecting the free market against democratic as well as capitalist interference. This was not just a departure but a reversal of its original intent, the idea of an economic constitution prefigured by Frankfurt school theorists Franz Neumann and Hugo Sinzheimer had signified democratic control of the economic structures of society; it was a labour constitution. ${ }^{83}$

The new economic constitutionalism, based on formal equality, and individual economic rights would mean the complete abolition of class conflict

\footnotetext{
${ }_{78}$ J W Müller, Contesting Democracy (Princeton University Press, 2012)

79 See C Möllers, 'We are (afraid of) the People: Constituent Power in German Constitutional Thought', in M Loughlin and N Walker (eds) The Paradox of Constitutionalism.

${ }^{80}$ C J Friedrich, 'The Political Thought of Neo-liberalism', American Political Science Review 49 (1955); Michel Foucault, The Birth of Biopolitics - Lectures at the College de France 1978-1979 New York, Palgrave MacMillan, 2008)

81 Friedrich, ibid.

82 Cf Hannah Arendt, On Revolution (London, Penguin, 1958), 184

83 See R Dukes, The Labour Constitution (Oxford, OUP, 2012).
} 
from the political domain. ${ }^{84}$ The class-conscious democratic struggles of the interwar period would be repressed in order to secure political and economic stability. The new civil religion was fiscal prudence, efficiency and competition.

Although it was far from straightforwardly applied, ordoliberalism's particular constitutional prescriptions represented a reconfiguration of the constitutional imagination, specifically regarding the political-economic relation. Its ideological linkage of neoclassical market economics and liberal constitutionalism would become a key conceptual plank in the process of European integration. ${ }^{85}$ The ordoliberal legacy could be seen, for example, in how the self-understandings of constitutional actors in Europe (in particular the ECJ and the European Commission) became increasingly conditioned by ideologies and interests that corresponded to the pressures of economic rationality and the logic of market competition. These trends become more acute in time, particularly after the Treaty of Maastricht, and of course extend far beyond the EU. The economic neo-liberalism that is captured in the literature on the 'new constitutionalism' can be understood as a direct descendent of ordoliberalism's critique of the dangers of constituent power and democracy. .66

Foundations addresses neither ordoliberalism nor European integration in any detail. But this is entirely consistent with Loughlin's avoidance of any politicaleconomic conceptualisation of the dynamic of state development, from Locke through to Polanyi. European integration thus features only in the very closing part of Foundations and is there presented as affecting only the category of potentia in the limited sense of governmentality. The final chapter of Foundations entitled 'the new architecture of public law' examines the growth of the administrative state, and this includes the impact of the EU, but only in so far as it modifies our understanding of 'government', and not of 'State' or 'Constitution'. ${ }^{87}$

Loughlin's reluctance to extend his dialectical approach to political ordering to the project of European integration leads him to suggest that the changes reflected by it are merely super-structural and, elsewhere, to insist that the formal right to leave means that potestas is basically untouched. ${ }^{88}$ In the vernacular of public law, sovereignty can entail membership of the European Union or exit from it, now in accordance with a Treaty to which each Member State is bound (Article 50, TFEU). Just as the constituent power to change the constitutional direction from ordoliberalism towards socialism theoretically remains, the governmental powers that are channelled through European institutions can be

\footnotetext{
${ }^{84}$ See E V Bonn, Standard Texts on Social Market Economy: Two Centuries of Discussion (ed. Horst Friedrich Wunsche) tr. Derek Rutter (Stuttgart, Gustav Fisher Verlag, 1982) ix.

85 Steph Dullien and Ulrike Guérot, 'The Long Shadow of Ordoliberalism: Germany's Approach to the Euro-crisis' European Council of Foreign Relations 49 (2012).

86 See Kanishka Jayasuriya, 'Globalisation, Sovereignty and the Rule of Law: From Political to Economic Constitutionalism', Constellations 8 (2001): 442.

87 Foundations, 435 - 467.

88 See e.g. M Loughlin, 'Why Sovereignty' in R Rawlings, P Leyland, and A Young (eds.) Sovereignty and the Law (Oxford, Hart, 2013).
} 
reclaimed. The channelling of authority occurs in accordance with a constitution that can itself be changed by the constituent power of the nation. There is thus a way to reconcile ordoliberalism, as well as European integration, with the autonomy of the political realm. For both, strictly speaking, it remains a political decision that is the basis for the economic or supranational constitutional arrangements.

But once politics is reduced to a single political-economic logic, and the possibility of genuine renewal comes down to the possibility of exercising the constituent power, the autonomy of the political is reduced to a bare formality or the prospect of a revolutionary rupture. Constituent power might even be temporarily absorbed into a new regime of constituted power, based on constitutional rights, protected by constitutional courts, or managed by other institutions.

This reversal is captured in the discourse of 'de-politicisation', where issues of appropriation, distribution and production are increasingly taken out of the public political sphere of contestation, and determined by market logic, or the technocratic bodies who are supposed to replicate it. The process of depoliticisation (which would better be termed 'de-democratisation') can even be constitutionalised, as in the Eurozone, with the structural and institutional prescriptions of Economic and Monetary Union in the Treaty of Maastricht, and defended by the European Central Bank and Court of Justice. But it can also be channelled through political ideology, such as in the refrain that 'There is no alternative' to neo-liberal structural reform (so-called TINA).

The post-war shifting of boundaries between the political and the economic is especially evident in public law's constitutionalist variant, where not only a private micro-economic sphere, but increasingly a macro-economic sphere is insulated from politics through legal-institutional means - with constitutional courts, central banks and supranational institutions increasingly determining political principles and conditioning political outcomes. ${ }^{89}$ And what must be captured is not only formal channelling but constitutionalism's framing function, the way a constitution (understood broadly) establishes not just how political debate is to be organised, but what its limits are..$^{90}$

Potestas is not captured by formal possibilities alone; it integrates an element of subjective belief about the right to rule, in combination with the perceived capacity to govern. Ordoliberalism and European integration do not only set in motion a series of new institutions and governmental arrangements. Contrary to what Foundations suggests, these reflect and in turn reconstitute a deeper set of beliefs about the governing relationship. There has been not only a

\footnotetext{
${ }^{89}$ See e.g. K Tuori and K Tuori, The Eurocrisis: A Constitutional Analysis (Cambridge, CUP, 2013).

90 As Gavin Anderson puts it, 'constitutional discourse is always more than the rules it generates or legitimates... setting the parameters not just for how politics is contested, but what is deemed politically contestable'. See G. Anderson, in S Gill, New Constitutionalism and World Order (Cambridge, CUP, 2015) 283, quoting Christodoulidis.
} 
'quantitative' change in governing activities, an increase in delegation and pooling of governmental powers, but a 'qualitative' shift in the political constitution of the state, a transformation of the basic idea of the right to rule itself. It is, in other words, in relation to potestas as much as potentia that the post-war constitutional imagination is reborn, a structural reconfiguration of the state, as a new ideal type of political-economic community, albeit one whose lineages can be traced back to ideas associated with classical liberalism. According to Giandomineco Majone:

The possibility of separating economics and politics was a key, if implicit, assumption of the founders of the EEC. It was not a new idea but rather a return to a classical liberal tenet which in the nineteenth century and up to world war I had made it possible for the world economy to develop in such a fashion that "between national and international economic integration there was only a difference in degree but not in kind". ${ }^{1}$

To fully capture integration as part of this process of state transformation, Chris Bickerton's analysis is useful, not least since he builds on Loughlin's own schema as outlined in Foundations. Drawing on integration studies and work in critical political economy, Bickerton conceptualises the transformation of the 'nationstate' into a 'member state' as a feature of membership of the EU. ${ }^{92} \mathrm{He}$ argues that European integration, in a second phase (after the post-war trentes glorieuses) beginning in the mid-late 1970's, has transformed the state by transforming, or more specifically, opposing (rather than uniting) state - society relations, separating the state and its sovereign power from the popular will. This is because, regarding the limiting of national power - central to the modern constitutional imagination - European integration 'is different from the acts of self-binding by the modern state: '[t]he active subject, namely the people, is not doing the binding. ${ }^{93}$ This reflects not just a superficial change to the 'architecture of public law' or to the category of potentia but a dismantling of the social contract or the right to rule:

Constraints upon the exercise of national power are based not upon a political ideal or principle but rather on an institutional and bureaucratic understanding of such limits. The picture we thus have of the member state... is one of administrative machine rather than a political community. We are in the realm of what Engels called 'the administration of things. ${ }^{94}$

The constitutional re-imagination of neo-liberalism is wide-ranging. Political and social identity is fragmented, increasingly commodified and quantified as merely

${ }^{91}$ G Majone, 149, Rethinking the Union of Europe Post-Crisis (Oxford, OUP, 2014), citing Röpke.

${ }^{2}$ C Bickerton, European Integration: From Nation-State to Member State (Oxford, OUP, 2012)

93 Bickerton, 67

${ }^{94}$ Bickerton, 69. 
consisting of a particular collection of individualist tastes and preferences. The citizen is replaced by a simple consumer of economic benefits. And in terms of the political responsiveness of the new 'debt state' and its institutions in this period, the constituency that matters is no longer the Statsvolk, but the Marktsvolk, 'inaugurating a new stage in the relationship between democracy and capitalism'. ${ }^{95}$ The dominant means for the state to collect resources shifts from reliance on its citizens through direct taxation, to reliance on financial investors in the global marketplace.

These changes, of course, were only fully realised in the context of momentous geopolitical, political and ideological shifts that transform Europe at the end of the 'short twentieth century', marked with the collapse of the Soviet Union. But the neo-liberal phase, on the view offered here, represents an exaggeration of post-war trends rather than a departure from them. European integration, right from its initial formation, is properly conceived as a response to the series of interwar dynamics sketched above, both reflecting and helping to set in train a process of state transformation based on restrained democracy (and tempered by restrained capitalism).

This is a complex and uneven process, and each country stands in a different material relation with the project of integration, making conceptual generalisation problematic. Thus, the British relationship to the project is quite different from the 'founding six' (Germany, Italy, France and Benelux), as well as the post-Fascist Mediterranean accessions and post-Communist entries, not only geo-politically, institutionally and culturally, but also temporally - joining at the end of the Golden Age of Keynesian governmentality rather than at the beginning of post-war reconstruction or the end of the Cold War. But abstracting from these significant differences, and to adopt Loughlin's own conceptual dichotomy, the changes inaugurated by the project of restrained democracy go not only to the question of potentia, but also to the question of potestas (and to the dynamic relation between potestas and potentia). It reflects a change in this basic dynamic not because of any return of the religious as a threat to the autonomy of the political, but because the right to rule is no longer extended to those who would fundamentally question the differentiation of the political and the economic as demanded in the new post-war order of liberal political economy, and in which European integration plays a central and increasingly prominent role.

To put it (too) bluntly, in the post-war constitutional settlement the Communist Party of Germany does not have the right to rule, at least not according to the German Constitutional Court. ${ }^{96}$ But neither can the right to rule include the right to relinquish a commitment to the project of European

\footnotetext{
${ }^{95}$ See e.g. Wolfgang Streeck, Buying Time (London: Verso, 2014), 79-88.

${ }^{96}$ See D Kommers and R Miller, The Constitutional Jurisprudence of the Federal Republic of Germany (Durham, NC, Duke University Press, 2012), 291. A more informal bargain might be identified in the commitment of the British labour party to the parliamentary route to socialism or with the Eurocommunism of continental European communist parties.
} 
integration, now updated to exclude any questioning of the single currency as representing the fate of the continent ('if the Euro fails, Europe fails'). On the other hand, nor can the government 'surrender' the right to rule over 'essential state tasks' to the EU, as the Lisbon ruling of the German Constitutional Court would later insist, precluding the development of a European federal state. ${ }^{97}$

The post-war reconstitution of the modern state is not just an attempt to tame the passions unleashed in the interwar period through various regimes of governmentality. It reflects a basic re-orientation of the constitutional imagination and a new ground of legitimate authority, an inversion even of the relation between the political and the economic, based on the primacy of the economic. Although this is far from an irreversible formation - and it will come to generate new sets of tensions between the political and the economic, democracy and capitalism, that continue to reverberate - it marks a transformation in the constitution of the state and state-system.

The European project is integral to this resetting of the political-economic relation. But its political form is ambiguous. To this day, it remains in limbo: not a mere international organisation, but neither a fully-fledged federal super-state. In fact, it bears a strong resemblance to Schmitt's notion of a federation or Bund, a form that is inherently unstable in Schmitt's view. ${ }^{98}$

Of course, the formal right to leave the EU exists, marking it as distinct from the normal federation. But leaving would represent a material re-constitution of the state, particularly for those in the Eurozone. To be sure, sovereignty, held in abeyance, suspended in the post-war European federal construct, is now back on the agenda. Is there a better expression of the desire for a reclaiming of politics vis-à-vis the economic than the conditions surrounding 'Brexit'? And yet if the event shows the relative autonomy of the political, the difficulty in acting on it reveals the relative autonomy of the political.

This cannot be more fully developed here, but the point should be clear enough: the crisis of the contemporary state and the regional state-system in Europe is fully material in nature, and revolves around the political-economic struggles between democracy and capitalism, as much within as between states, in a reprisal, albeit in different conditions, of the interwar interregnum. ${ }^{99}$ This is why the fragility of public law returns in plain sight.

\footnotetext{
${ }^{97}$ See M Wilkinson, 'Political Constitutionalism and the European Union' (2013) Modern Law Review 191 222.

98 C Schmitt, Constitutional Theory (trans. J. Seitzer) (Duke University Press, 2008). See also O Beaud Théorie de la Fédération; C. Schönberger, "Die Europäische Union als Bund" 129 (1) Archiv des öffentlichen Rechts, March 2004; R Schütze, "Federalism as Constitutional Pluralism: 'Letters from America"' in Constitutional Pluralism in the European Union and Beyond, edited by Avbelj and Komarek, above; M. Avbelj, “Theory of European Union” (2011) European Law Review 2011.

${ }^{99}$ For a fuller account, see M Wilkinson, "The Reconstitution of Postwar Europe: Liberal Excesses, Democratic Deficiencies' in M Dowdle and M. Wilkinson (eds.) Constitutionalism Beyond Liberalism (Cambridge, Cambridge University Press, 2017).
} 


\section{CONCLUSION}

If Hegel represents the last standard-bearer of an idealist political jurisprudence, Schmitt marks its twilight, providing the clearest sense that the modern dialectic of potestas and potentia is marked by significant discontinuities, and even rupture. This emerges forcefully in the interwar era but reverberates beyond, into the post-war reconstruction of the European state and state-system. It is far from being resolved, as that reconstruction now comes under sustained pressure in the recent period of crises.

Loughlin's turn to nomos in order to provide firmer ground for the foundations of public law is indicative of a renewed period of tension in the contemporary state form - when, again, its ability to maintain political order is placed in question. This turn is material but in a quite specific and limited way, maintaining public law's distance from any reconnection with the tradition of political-economy (either classical liberal or critical-Marxist).100 Without any account of the political-economy and geo-politics of the threefold ordering of nomos, land appropriation simply becomes a material mirror-image of the Kelsenian presupposition, a Grund-nomos. For Loughlin, gesturing towards a more reflexive account than Schmitt, ${ }^{101}$ nomos continues to evolve, because the state expresses 'the dynamic emergence of political unity, of the process of constantly renewed formation and emergence of this unity from a fundamental or ultimately effective power or energy.'102 Energy, of course, cannot be created or destroyed, but only transformed. But from what, and into what? And what opposing material forces does political energy encounter?

According to Loughlin, the most basic purpose of the practices of modern public law was that of maintaining the civil peace against a backdrop of (often violent) competing truths.' ${ }^{103}$ Auctoritas non veritas facet legem, as Hobbes taught. But what were these truths about?

It is not only 'truths' that are competing, but also material and ideological interests and relations, and they are in constant motion. Reflexivity cannot do the necessary work of capturing this dynamic. The meaning of the political equality that is required to generate reflexive order in practice is never elaborated by Loughlin, nor are the material reasons for its fragility in a market society explored. The key conceptual-historical argument advanced here is that the dynamic of political ordering is conditioned by the material relation between democracy and capitalism as real social forces. The advantage of foregrounding this politicaleconomic relation as a matter of state formation is that it brings us closer to what the processes and institutions of public law actually $d o$, closer to how this relation

100 Loughlin, note 2 above.

101 Loughlin, above (29?).

102 Loughlin, 'Politonomy'.

103 Foundations, 465 
is materially constituted and regulated, as well as how public law can be threatened by it, from capitalism on the one side, and democracy on the other.

Processes of political and economic ordering take place across two spheres, which are only relatively autonomous from one another. To maintain the relative autonomy and primacy of the political requires a degree of democratic political control over the economy and our material social relations. It is the autonomy of the political realm that allows politics to occur, to permit political contest between different economic models or substantive social goals, for example, or to reorganise or recondition the taking, distribution and production of land and resources. But this control can be lost, eroded or at least marginalised through the hegemony of particular political-economic structures, ideas and interests in a capitalist society and state-system. It can also be regained by struggles for the relative autonomy of the political realm, through movements that build on and generate solidarity and co-operation. Would it not be imprudent to reduce struggles for equal liberty to a matter of functional or scientific logic alone? 